\title{
PODERES E LIMITES DAS COMISSÕES PARLAMENTARES DE INQUÉRITO NO BRASIL
}

\section{POWERS AND LIMITS OF THE LEGISLATIVE INVESTIGATING COMMITTEES IN BRAZIL}

\author{
Eduardo Martins de Lima ${ }^{1}$ \\ Flávia Cristina Mendonça Faria Da Pieve
}

\section{RESUMO}

O presente trabalho dedica-se ao estudo dos poderes e limites outorgados às comissões parlamentares de inquérito pela Constituição da República de 1988 e leis infraconstitucionais. O poder investigativo das comissões parlamentares de inquérito é considerado um importante instrumento de controle da Administração Pública. Para o desempenho da função investigativa, o art. 58, $\S 3^{\circ}$, da Constituição da República, conferiu às comissões parlamentares de inquérito "poderes de investigação próprios das autoridades judiciais". Contudo, tais poderes não são ilimitados, motivos pelos quais se impõe a investigação de seus limites.

Palavras-chave: Comissões parlamentares de inquérito. Poder Legislativo. Controle político. Preceitos constitucionais.

\section{ABSTRACT}

The powers and limits conferred upon the Legislative Investigating Committees by the Brazilian Constitution and the infra-constitutional statutes constitute the object of the paper herein presented. The investigating authority of the Investigating Committees is considered to be of utmost importance as a means of control of the Public Administration. In fact, article 58, $§ 3$ of

\footnotetext{
${ }^{1}$ Doutor em Sociologia e Política, Mestre em Ciência Política pela Universidade Federal de Minas Gerais - UFMG, Minas Gerais, (Brasil). Bacharel em Direito, pesquisador e professor da Universidade FUMEC. (Brasil).

E-mail: edumlima@ fumec.br.

2 Mestranda em Direito pela Universidade FUMEC. (Brasil). Área de Concentração: Instituições Sociais, Direito e Democracia, Linha de Pesquisa: Esfera Pública, Legitimidade e Controle. Auditora-Geral do Município de Belo Horizonte. E-mail: flaviafaria@yahoo.com.
} 
the Brazilian Constitution sets out that the referred to Committees are attributed powers inherent to those of judicial authorities, aiming at carrying out the pursuing task. However, the above mentioned powers are not unconditional. Therefore, the research of the limits herein mentioned is necessary.

Keywords: Legislative Investigating Committees. Legislative Power. Political control. Constitucional Rules.

\section{INTRODUÇÃO}

As Comissões Parlamentares de Inquérito - CPI's, previstas no $\S 3^{\circ}$ do art. 58 da Constituição da República, deverão ter como função precípua auxiliar o Poder Legislativo no exercício de suas funções legiferante, fiscalizadora e de controle da Administração Pública. Ainda, configuram importante instrumento de controle político à disposição da minoria, já que deverão ser criadas se apresentado requerimento subscrito por um terço dos parlamentares.

As investigações a cargo das CPI's devem ter em conta questões de relevante interesse público, tais como assuntos que atentam contra a ordem econômica, administrativa, política e jurídica. Por intermédio das CPI's, o Poder Legislativo poderá aprofundar no estudo de determinados temas, para aperfeiçoamento da legislação, razão pela qual o objeto de investigação deverá ser somente sobre matéria de competência outorgada pela Constituição da República à respectiva Casa Legislativa ou ao próprio Congresso Nacional, se for mista.

O tema ganha relevo quando se indaga se estão os parlamentares, membros das CPI's, habilitados tecnicamente a desempenhar poderes de investigação próprios das autoridades judiciais (art. 58 da Constituição da República de 1988), bem como quais atos são de competência exclusiva do Poder Judiciário.

Cumpre analisar se certos poderes de investigação, tais como a quebra de sigilos bancário, fiscal e telefônico e busca domiciliar, são passíveis de serem exercidos pelo Poder Legislativo ou se a própria Constituição os reserva com exclusividade ao Poder Judiciário. 


\section{Comissão Parlamentar de Inquérito: definição e sua utilização como instrumento controlador}

Comissões parlamentares são pequenos grupos formados por parlamentares, com o objetivo de facilitar as divisões de tarefas no âmbito das Casas Legislativas, seja em razão da matéria, seja em razão de sua função. Assim, as comissões parlamentares, prolongamentos ou longa manus dos respectivos Parlamentos, poderão ser, nos termos do caput do art. 58, da Constituição da República de 1988, permanentes ou temporárias, constituídas na forma e com as atribuições previstas no respectivo regimento ou no ato de que resultar sua criação.

A CPI, espécie de comissão temporária, prevista no $\S 3^{\circ}$, do art. 58, da Constituição de 1988, constitui, como já dito, importante instrumento de controle à disposição do Poder Legislativo para exercer seu poder de investigação de fatos relacionados ao próprio Poder Legislativo, bem como aos Poderes Executivo e Judiciário.

Os trabalhos desempenhados pela CPI são de cunho meramente investigatórios e, assim, não julgam, não impõem penas, tampouco acarretam a perda de mandato eletivo. As conclusões extraídas dos trabalhos de tais comissões são meramente informativas e opinativas, sendo, posteriormente, encaminhadas, se for o caso, às autoridades competentes para adoção de medidas que visem a responsabilização civil e/ou criminal.

\section{Comissões Parlamentares de Inquérito no Constitucionalismo Brasileiro}

A Constituição Imperial, outorgada em 25 de março de 1824, instituiu a forma unitária de Estado e a monarquia como forma de governo. Essa Constituição sofreu forte influência de Benjamin Constant, com a criação do denominado Poder Moderador, que atribuía ao Monarca toda a organização político-administrativa do Império, bem como lhe permitia total controle e ingerência nas funções legislativa, executiva e judiciária. Dessa maneira, a única forma de 
controle era exercida exclusivamente pelo Monarca e, por óbvio, a Carta de 1824 não autorizou expressamente a criação de CPIs no âmbito do Legislativo ${ }^{3}$.

Segundo José Alfredo de Oliveira Baracho, “[...] durante o Império não ocorreu a constituição de inquéritos parlamentares que tivessem como objetivo investigar a atuação do Executivo" (BARACHO, 2001, p. 102).

Todavia, Luiz Carlos dos Santos Gonçalves anota que “[...] a Carta Constitucional de 1824 já menciona uma comissão, da Câmara dos Deputados, cuja tarefa era examinar as proposições do Poder Executivo, condição para que elas pudessem ser consideradas projetos de lei” (GONÇALVES, 2001, p. 33).

Jessé Cláudio Franco de Alencar (2005, p. 17), citando Nelson de Souza Sampaio, destaca que a Carta de 1824 previa, implicitamente, a investigação parlamentar, em seu art. 15, VI, ao prever a possibilidade da Assembleia Geral, em caso de morte do Imperador ou vacância do trono, instituir exame da administração que acabou e reformar os abusos nela introduzidos ${ }^{4}$.

Ainda que ausente previsão constitucional expressa, noticia-se a instauração de investigações sobre questões comerciais, industriais, agrícolas, dentre outras, no âmbito da Assembleia Geral, formada pela Câmara dos Deputados e pelo Senado, como destacado pelo então Ministro do Supremo Tribunal Federal (STF) Paulo Brossard, Relator do Habeas Corpus $\mathrm{n}^{\circ}$ 71.039-RJ ${ }^{5}$, em voto que aborda o tema sobre a criação de comissões de inquérito na época do Império.

A primeira Constituição da República, promulgada em 24 de fevereiro de 1891, estabeleceu a forma federativa de Estado, instituindo o federalismo dualista mediante a separação de competências entre a União e os Estados-membros, bem como a República como forma de governo. Apesar da influência de Montesquieu, com a divisão das funções do Poder (legislativa, exercida pelo Congresso Nacional, formado pela Câmara dos Deputados e Senado; executiva,

\footnotetext{
${ }^{3}$ Há um trabalho de Eduardo Martins de Lima com Flávia Cristina Mendonça Faria Da Pieve e João Costa Aguiar Filho que trata da CPI no ordenamento jurídico, situando sua origem, histórico, atribuições e limites (LIMA; DA PIEVE, AGUIAR FILHO, 2011).

${ }^{4}$ Art. 15. É da atribuição da Assembleia Geral: [...]

VI - Na morte do Imperador, ou vacância do Trono, instituir exame da administração que acabou, e reformar abusos nela introduzidos.

${ }^{5}$-Disponível em:

<http://www.stf.jus.br/portal/jurisprudencia/listarJurisprudencia.asp?s1=\%2871039\%2ENUME\%2E+OU+71039\%2

EACMS\%2E\%29\&base=baseAcordaos\&url=http://tinyurl.com/hpf8qxg>. Acesso em: 7 set. 2016.
} 
desempenhada pelo Presidente da República e judiciária, estrutura no âmbito da União e dos Estados-membros), a Constituição de 1891 continuou silente sobre a criação de inquérito parlamentar.

Contudo, José Alfredo de Oliveira Baracho noticia que, “[...] apesar da ausência de preceito constitucional, foram propostos na Câmara 19 (dezenove) inquéritos parlamentares" (BARACHO, 2001, p. 104), demonstrando-se, mais uma vez, que nem mesmo o silêncio da Constituição foi capaz de inibir o Legislativo de instaurar investigações sob a égide da Constituição de 1891.

Nova Constituição foi promulgada, em 16 de julho de 1934, rompendo com a concepção liberal de Estado e demonstrando preocupação com questões sociais, sendo a primeira a trazer expressa previsão das CPI's, em seu art. $36^{6}$, restringindo tais investigações ao âmbito da Câmara dos Deputados.

Durante o Estado Novo foi outorgada nova Constituição, em 10 de novembro de 1937, alcunhada de Constituição polaca, já que Getúlio Vargas inspirou-se na Carta ditatorial da Polônia de 1935. Nessa época de ditadura, as entidades federadas foram totalmente descaracterizadas e não interessava qualquer forma de controle do Poder político, razão pela qual a Constituição de 1937 silenciou-se, novamente, sobre as CPI's, prevendo, apenas, em seu art. 45, que "qualquer das duas Câmaras ou alguma de suas Comissões pode convocar Ministro de Estado para prestar esclarecimentos sobre as matérias sujeitas à sua deliberação".

Com o advento da Constituição de 1946, promulgada em 18 de setembro desse ano, após a queda de Getúlio Vargas e o fim da Segunda Guerra Mundial, imbuída do espírito da redemocratização, são ressurgidas as CPI's, em seu art. 53, dispondo que "a Câmara dos Deputados e o Senado Federal criarão Comissões de Inquérito sobre fato determinado, sempre que o requerer um terço de seus membros”.

Foi no período de vigência da Constituição de 1946 que se editou a Lei no 1.579 , de 18 de março de 1952, a primeira lei federal, de caráter nacional, a disciplinar as CPI's, ainda vigente hoje.

\footnotetext{
${ }^{6}$ Art. 36. A Câmara dos Deputados criará comissões de inquérito sobre fatos determinados, sempre que o requerer a terça parte, pelo menos, dos seus membros.
} 
Manoel Messias Peixinho e Ricardo Guanabara noticiam que, sob a égide da Constituição de 1946, foram criadas duzentas e quarenta CPI's pela Câmara dos Deputados e treze pelo Senado Federal (2001, p. 44).

Em 1953, o Supremo Tribunal Federal julgou o Recurso em Habeas Corpus $\mathrm{n}^{\circ}$ 32.678/DF ${ }^{7}$, Relator Min. Mário Guimarães, considerado leading case. O referido habeas corpus fora impetrado pelo então Presidente do Jornal Última Hora contra ato da CPI instituída pela Câmara dos Deputados para "apurar fato determinado constante de responsabilidade pelas relações entre o Banco do Brasil e empresas jornalísticas do Brasil”.

A Constituição de 1967, formalmente promulgada em 24 de janeiro desse ano, em seu art. 39, trouxe a previsão de que "a Câmara dos Deputados e o Senado Federal, em conjunto ou separadamente, criarão comissões de inquérito sobre fato determinado e por prazo certo, mediante requerimento de um terço de seus membros”. Manoel Messias Peixinho e Ricardo Guanabara destacam a importância das CPI's sob a égide da Constituição de 1967:

\begin{abstract}
Restabelecida a presença constitucional das comissões parlamentares de inquérito, tal instituto teve uma presença marcante na história política do período de 1945 a 1965. Alguns episódios, como a comissão parlamentar de inquérito da "Última Hora", de 1953, que investigou as transações do jornal com o Banco do Brasil, e a comissão parlamentar de inquérito, criada em 1963, para investigar a tentativa de prisão, seqüestro ou eliminação do Governador Carlos Lacerda, foram eventos com grande repercussão no cenário político do país (PEIXINHO; GUANABARA, 2001, p. 43).
\end{abstract}

A denominada Emenda Constitucional $n^{\circ}$ 01, outorgada por uma junta militar, em 17 de outubro de 1969, tendo em vista a sua amplitude, não modificou o art. 39 da Constituição de 1967, mas tão-somente o renumerou para o art. 37. Contudo, em seu art. 30, alínea $e$, limitou, em cinco, o número de comissões parlamentares concomitantes, além de proibir despesas com viagens para seus membros na alínea $f$ (redação dada pela Emenda Constitucional n. 11, de 13 de outubro de $\left.1978^{8}\right)$ :

\footnotetext{
${ }^{7}$ Disponível em:

<http://www.stf.jus.br/portal/jurisprudencia/listarJurisprudencia.asp?s1=\%2832678\%2ENUME\%2E+OU+32678\%2 EACMS\%2E\%29\&base=baseAcordaos\&url=http://tinyurl.com/hx7w6ol $>$. Acesso em: 7 set. 2016.

${ }^{8}$ Art. $30[\ldots]$

e) não será criada comissão parlamentar de inquérito enquanto estiverem funcionando concomitantemente pelo menos cinco, salvo deliberação por parte da maioria da Câmara dos Deputados ou do Senado Federal;

f) a comissão parlamentar de inquérito funcionará na sede do Congresso Nacional, não sendo permitidas despesas com viagens para seus membros.
} 
Com o enfraquecimento do Poder Legislativo frente ao Poder Executivo, ocasionado pela edição da Emenda Constitucional no 01/1969, entre 1969 e 1973 foi criada apenas uma CPI na Câmara dos Deputados (PEIXINHO; GUANABARA, 2001, p. 47).

A Constituição democrática de 1988 trouxe destacadas modificações sobre as CPI's e fortaleceu o controle parlamentar a ser exercido por tais comissões:

Art. 58. O Congresso Nacional e suas Casas terão comissões permanentes e temporárias, constituídas na forma e com as atribuições previstas no respectivo regimento ou no ato de que resultar sua criação.

$\S 3^{\circ}$ - As comissões parlamentares de inquérito, que terão poderes de investigação próprios das autoridades judiciais, além de outros previstos nos regimentos das respectivas Casas, serão criadas pela Câmara dos Deputados e pelo Senado Federal, em conjunto ou separadamente, mediante requerimento de um terço de seus membros, para a apuração de fato determinado e por prazo certo, sendo suas conclusões, se for o caso, encaminhadas ao Ministério Público, para que promova a responsabilidade civil ou criminal dos infratores (grifos nossos).

A partir da leitura do art. 58, $\S 3^{\circ}$, da Constituição, destacam-se as seguintes características das CPIs:

a) decorrem da função fiscalizadora e controladora do Poder Legislativo;

b) têm caráter temporário e prazo certo;

c) são destinadas a apurar fato determinado;

d) a criação será automática mediante o requerimento de um terço dos membros da Casa Legislativa, não se exigindo submissão ao Plenário da Casa Legislativa;

e) "terão poderes de investigação próprios das autoridades judiciais";

f) se for o caso, encaminhamento das conclusões ao Ministério Público para eventuais providências.

Ao tratar da CPI na Constituição da República de 1988, Plínio Salgado destaca que as características inovadoras de poderes de investigação próprios das autoridades judiciais e encaminhamento das conclusões ao Ministério Público, se for o caso, foram inspiradas nas Constituições da Itália (art. 82) e da Espanha (art. 76, I), respectivamente (SALGADO, 2001, p. 52). 


\section{Diferença entre os poderes atribuídos aos membros das Comissões Parlamentares de Inquérito na Itália e no Brasil}

A Constituição Italiana foi a primeira a positivar, servindo de inspiração para a Constituição brasileira, no sentido de que as CPI's teriam poderes próprios das autoridades judiciais:

Art. 82 - Ciascuna Câmera può disporre inchieste su materiae di publico interesse. A tale scocpo nomina fra i propri componenti una comissione formata in modo da rispecchiare la proporzione dei vari gruppi. La commissione d'inchiesta procede alle indagini e agll esami com gli stessi poteri e le stessi limitazioni dell'autorità giudiziaria. ${ }^{9}$

Luiz Carlos dos Santos Gonçalves relata que "[...] as comissões de investigação na Itália recebem disposição constitucional expressa e se inserem como mecanismo importante para o funcionamento do regime de gabinete" (GONÇALVES, 2001, p. 22).

Pela simples leitura do art. 82 da Constituição Italiana, é possível concluir a sua forte influência no instituto das CPI's no Brasil, com o advento da Constituição da República de 1988, ao conferir aos membros de suas comissões de inquéritos os mesmos poderes e limites da autoridade judicial.

Para delimitar o alcance da expressão "poderes próprios de autoridades judiciais" (art. 58 , $\S 3^{\circ}$, da Constituição de 1988$)^{10}$, impõe-se esclarecer que autoridades judiciais são aquelas responsáveis, primordialmente, pelo desempenho das funções jurisdicionais, segundo os critérios formal e material, que consistem em aplicar a lei aos casos concretos, por meio de atos jurisdicionais. As autoridades judiciais são os titulares dos cargos do Poder Judiciário, praticando, com exclusividade, determinados atos jurisdicionais, atendendo o próprio texto constitucional, como se verá adiante.

\footnotetext{
${ }^{9}$ Art. 82 - Qualquer das Câmaras pode decidir a realização de inquéritos em matérias de interesse público. Para este fim nomeia uma comissão de seus membros, respeitando a proporção dos vários grupos. As comissões de inquérito procedem as averiguações e aos exames com os mesmos poderes e limites da autoridade judicial (tradução nossa). ${ }^{10}$ Os autores LIMA e CARDOSO, em trabalho de 2014, desenvolvem o tema relativo aos poderes instrutórios e de investigação das CPI's, incluindo a análise sobre o inquérito no ordenamento brasileiro (LIMA; CARDOSO, 2014).
} 
Para compreender se às autoridades judiciais foram conferidos poderes investigatórios, será imprescindível pontuar as principais características do sistema processual penal no Brasil e na Itália, já que a Constituição Italiana, ao atribuir às suas CPI's poderes de investigação típicos dos magistrados, inspirou a Constituição Brasileira, como já dito.

O sistema processual penal italiano não guarda qualquer correspondência com o brasileiro. Na Itália, dentro da carreira da magistratura, tem-se o magistrado requerente, que se assemelha aos promotores de justiça brasileiros, e o magistrado judicante, equivalente aos juízes brasileiros. Assim, as funções de investigação e julgamento não se concentram na mesma pessoa, como adverte Flávio Meirelles Medeiros:

$\mathrm{Na}$ Itália, existe a magistratura requerente (como nossos promotores) e a magistratura judicante (como nossos juízes). No país da operação mani pulite, ambas as carreiras pertencem ao Poder Judiciário. O concurso é o mesmo além de possuírem as mesmas garantias. Como no Brasil, os promotores têm absoluta independência e podem, também, fazer investigações. Os responsáveis pelo êxito da Operação Mãos Limpas são os dois tipos de magistrados italianos - juízes e promotores - e não somente os primeiros. Lamentavelmente os meios de comunicação passaram a informação incorreta. Quando os brasileiros vibraram com a visita de magistrados italianos que vieram falar da Operação Mãos Limpas, tivemos a impressão de que os visitantes eram juízes como os nossos. Ledo engano. Tratava-se, também, de magistrados requerentes (promotores). É bom lembrar que a reforma do Código Processual Penal da Itália, de 1988, garantiu a separação das funções de acusar e de julgar, preservando os direitos individuais do acusado. Enquanto alguns no Brasil querem o juizado de instrução, na Itália ele já foi extinto. Para quem não sabe: na Itália, a fase judicial é precedida de investigações preliminares a cargo do magistrado do Ministério Público, que permanece com o controle processual da atividade da polícia judiciária. A polícia italiana apresenta, em regra, ao Ministério Público um relatório sobre a infração penal, e a partir daí começa a colheita de prova perante o juiz (MEDEIROS, 1994, p. 18-19).

Ao conhecer o sistema processual penal italiano, pode-se concluir que o art. 82 da Constituição Italiana atribuiu às comissões parlamentares os mesmos poderes de investigação do magistrado requerente.

No Brasil, adota-se o sistema acusatório ou sistema de inquérito policial, no qual a investigação criminal é realizada por autoridade policial civil (nos Estados) ou federal (no nível da União), sob a presidência dos delegados de polícia, cabendo ao Juiz tão-somente a instrução e o julgamento do processo.

Dessa maneira, no sistema processual penal brasileiro, o juiz, em regra, não produz provas, não detém o poder de investigação. Contudo, excepcionalmente, diante de mandamento 
constitucional expresso, o magistrado brasileiro exercerá poderes de investigações, no exercício de função eminentemente administrativa e não jurisdicional, visando resguardar o interesse público. No uso dessa excepcional prerrogativa, o magistrado poderá exercer poderes de investigação, quando, por exemplo, expede mandado de busca e apreensão e determina a quebra de sigilos bancário, fiscal e telefônico. Tais poderes de investigação, ou melhor dizendo, instrutórios, não se confundem com os poderes de cautela do magistrado, como é o caso de decisão judicial que decreta a indisponibilidade de bens.

Logo, pode-se concluir que o art. $58, \S 3^{\circ}$, da Constituição da República, ao conferir aos parlamentares, que conduzem o inquérito parlamentar, os mesmos poderes de investigação das autoridades judiciais, não está aplicando erroneamente o sistema acusatório, vigente no Brasil, tampouco, inspirou-se equivocadamente no sistema processual penal italiano e no art. 82 da Constituição Italiana.

Os poderes de investigação próprios de autoridades judiciais conferidos às CPI's são os poderes de investigação outorgados excepcionalmente às autoridades judiciais brasileiras, sem com isso transgredir o sistema processual penal brasileiro, que é o acusatório, resguardando-se as garantias constitucionais da tutela jurisdicional (art. $5^{\circ}, \mathrm{XXXV}$ ), do devido processo legal (art. $5^{\circ}$, LIV), da garantia do acesso a justiça (art. $5^{\circ}$, LXXIV), da garantia do juiz natural (art. $5^{\circ}$, XXXVII e LIII), do tratamento paritário das partes (art. $5^{\circ}$, caput e inciso I), da ampla defesa (art. $5^{\circ}$, LV, LVI e LXII), da publicidade dos atos processuais e motivação dos atos decisórios (art. 93, IX) e da presunção da inocência (art. $5^{\circ}$, LVII).

Por oportuno, destaca-se o parágrafo único do art. $4^{\circ}$ do Código de Processo Penal:

Art. $4^{\circ}$ - A polícia judiciária será exercida pelas autoridades policiais no território de suas respectivas circunscrições e terá por fim a apuração das infrações penais e da sua autoria.

Parágrafo único: A competência definida neste artigo não excluirá de autoridades administrativas, a quem por lei seja cometida a mesma função.

O referido dispositivo estende a competência de investigação a outras autoridades administrativas, desde que exista autorização legal. Dessa forma, pode-se concluir que tal dispositivo prevê os poderes de investigação das comissões parlamentares de inquérito e, ainda, os atos praticados pelos parlamentares responsáveis pela condução do inquérito parlamentar, 
inclusive os investigatórios, são administrativos, ou seja, tais autoridades estão no exercício excepcional de função administrativa, assim como ocorre com as autoridades policiais na condução dos inquéritos policiais.

A delimitação dos poderes e limites das CPI's é questão polêmica que vem sendo enfrentada pela doutrina e pelos Tribunais, pois divergem sobre a interpretação e extensão dos "poderes de investigação próprios das autoridades judiciais", como preconizado pelo art. $58, \S 3^{\circ}$, da Constituição da República.

Segundo José Nilo de Castro, no Brasil, tal poder de investigação não é ilimitado e “indefensáveis são as investigações resultantes de capricho ou perseguição política, 'dando margem ao uso abusivo ou exorbitante dos poderes constituídos em benefício dessas Comissões do Poder Legislativo" (CASTRO, 2003, p. 58).

Já para Luiz Carlos dos Santos Gonçalves (2001, p. 19), os poderes investigatórios conferidos às CPI's são ilimitados, não sendo plausível igualar os poderes dos membros da comissão aos de cunho investigatórios dos juízes e depois estabelecer ressalvas ou restrições.

Defendendo a equiparação entre a CPI e o Poder Judiciário, Paulo Hamilton Siqueira Júnior afirma que:

O entendimento doutrinário, embora muito bem fundamentado, não encontra guarida no texto constitucional. Não há dúvida de que a Constituição equiparou a Magistratura à Comissão Parlamentar de Inquérito, no que tange aos poderes de investigação. É lógico que o princípio da reserva da jurisdição persiste no que se refere ao julgamento, aplicação de penas, etc. A equiparação ao Poder Judiciário ocorre no âmbito da investigação, é o que diz claramente a Constituição Federal. Caso contrário, o próprio texto constitucional teria previsto a ressalva. Quanto a essa matéria, a Lei Fundamental da Alemanha ressalvou o segredo da correspondência, das comunicações postais e das telecomunicações do âmbito de investigação das Comissões Parlamentares de Investigação (art. 44, 2) (SIQUEIRA JÚNIOR, 2007, p. 85).

Em sentido contrário, assevera Uadi Lammêgo Bulos (2001):

[...] a Carta Magna dá ao juiz o monopólio da primeira e última palavra no conjunto de situações específicas, as quais não poderiam ser examinadas por terceiros, pois seria um inusitado absurdo, leigos de conhecimentos técnico-jurídicos examinarem matérias afetas aos profissionais do direito, que cursaram universidade e se prepararam para desempenhar o munus judicante (BULOS, 2001, p. 58). 
Uadi Lammêgo Bulos (2001) defende que a expressão "poderes de investigação próprios das autoridades judiciais" não pode ser confundida com o poder geral de cautela dos juízes e, mais, que os membros das CPIs não podem agir como se juízes fossem:

\begin{abstract}
A terminologia 'poderes de investigação próprios das autoridades judiciais' serve para consignar a idéia de que as deliberações oriundas das comissões parlamentares de inquérito são imperativas, como sendo um direito que lhes assiste. É somente nesse aspecto que os seus poderes se assemelham aos dos juízes. E só. No mais, os seus atos não trazem a marca de auto-executoriedade. Por isso, suas intimações, requisições dentre outros atos praticados pelos seus membros, caso sejam descumpridos, só se tornarão cogentes por ordem do juiz. Apenas as decisões jurisdicionais é que se executam por si mesmas.

Muitos confundem "poderes de investigação próprios das autoridades judiciais" com poder geral de cautela dos juízes. Ledo engano. Uma CPI não poderá praticar medidas assecuratórias reais ou restritivas da liberdade alheia, como se possuísse o poder de cautela outorgado aos membros do Judiciário. Se fosse diferente, poderia tomar medidas afetas àqueles que exercem jurisdição.

Como os membros da CPI não podem proceder como se juízes fossem, não lhes é dado prender pessoas, salvo na hipótese de flagrante delito, ordenar busca e apreensão, seqüestro ou indisponibilidade de bens, muito menos proibir que o investigado se afaste do País. (BULOS, 2001, p. 919).
\end{abstract}

O autor chama atenção, ainda, que nem mesmo as Constituições da Itália, de Portugal, da Espanha, fontes inspiradoras da Constituição do Brasil, outorgaram poderes ilimitados às CPI's. Conclui-se que, nos países que utilizam a expressão "poderes de investigação próprios das autoridades judiciais, não se tem notícia desta ou daquela exegese doutrinária conferindo às CPI's a prerrogativa de praticarem atos de brutalidade política contrários à Constituição" (BULOS, 2001, p. 916).

Dessa maneira, é equivocado, a nosso sentir, a sugestão, por exemplo, constante do Relatório Final da CPI do Judiciário no sentido de "alterar a redação do $\S 3^{\circ}$, do art. 58, da Constituição Federal, para adotar redação semelhante à do art. 82 da Constituição Italiana, incluindo poderes acautelatórios, permitindo-se, assim, a decretação da indisponibilidade de bens pelas CPIs", já que, como dito, não é essa a interpretação que prevalece no direito comparado e na jurisprudência consolidada pelo Supremo Tribunal Federal - STF, que será analisada adiante.

\title{
5 Poderes das comissões parlamentares de inquérito sob a ótica do Supremo Tribunal
}

\section{Federal}


Em diversas oportunidades, o Supremo Tribunal Federal - STF decidiu sobre os poderes e limites das CPI's, como se passa a demonstrar.

O STF, desde 1999, consolidou entendimento no sentido de que as CPI's não possuem competência para decretar a indisponibilidade de bens ou medidas similares, tais como arresto, o sequestro ou a hipoteca judiciária, como consignado nos acórdãos prolatados nos autos dos Mandados de Segurança 23.480/RJ, DJU de 15/09/2000 e 23.466, DJU de 06/04/2001, ambos de relatoria do Ministro Sepúlveda Pertence ${ }^{11}$.

Por óbvio, os membros das CPI's estão adstritos aos mesmos limites formais a que se submetem os magistrados, quando da instrução criminal. Logo, as CPI's somente poderão ordenar prisões em flagrante delito, como por exemplo, pela prática de crime de falso testemunho perante a comissão, desde que a prisão seja devidamente motivada pelos seus membros, sob pena de ofensa ao art. $5^{\circ}$, inciso LXI, da Constituição da República.

Por tal motivo, é comum a impetração de habeas corpus por pessoas que, convocadas para deporem perante a CPI, na qualidade de investigado, testemunha, perito, tradutor ou intérprete, para que possam garantir o direito ao silêncio ou ao sigilo profissional.

Nesse sentido, decisão proferida pelo STF em sede de habeas corpus, tendo como autoridade coatora o Presidente da CPI destinada a investigar tráfico de pessoas no Brasil:

EMENTA: HABEAS CORPUS. CONSTITUCIONAL. COMISSÃO PARLAMENTAR DE INQUÉRITO - TRÁFICO DE PESSOAS NO BRASIL. REQUERIMENTO DE OITIVA DOS PACIENTES. DIREITO DE NÃO PRODUZIR PROVA CONTRA SI MESMO (NEMO TENETUR SE DETEGERE) E DE ASSISTÊNCIA DE ADVOGADO. ORDEM PARCIALMENTE CONCEDIDA. 1. A jurisprudência deste Supremo Tribunal firmou-se no sentido de ser oponível às Comissões Parlamentares de Inquérito a garantia constitucional contra a autoincriminação e, consequentemente, do direito ao silêncio quanto a perguntas cujas respostas possam resultar em prejuízo dos depoentes, além do direito à assistência do advogado. Precedentes. 2. Ordem parcialmente concedida.

\footnotetext{
${ }^{11}$ Disponível em:

<http://www.stf.jus.br/portal/jurisprudencia/listarJurisprudencia.asp?s1=\%28indisponibilidade+de+bens+cpi\%29\&b ase=baseAcordaos\&url=http://tinyurl.com/zospnnu $>$. Acesso em: 7 set. 2016.
} 
(STF - HC 11994-1/DF - Relatora: Ministra Cármen Lúcia, DJe de $28 / 04 / 2014^{12}$ )

Cumpre esclarecer que a regra constitucional que assegura o direito de a pessoa permanecer em silêncio e não se auto incriminar prescinde da impetração de habeas corpus preventivo, remédio judicial utilizado, inúmeras vezes, para se evitar eventual abuso de poder e espetáculos por parte dos membros das CPIs, principalmente em situações que mobilizam o país.

Destarte, configura importante poder das CPI's, instauradas nos níveis federal, estadual e municipal, a quebra dos sigilos bancário, fiscal e telefônico, que são inerentes à suas funções investigativas, nos termos do art. $2^{\circ}$, da Lei $\mathrm{n}^{\circ}$ 1.579, de 18 de março de 1952, art. 58, § $3^{\circ}$, da Constituição da República e Lei Complementar nº 105/2001.

É essa a orientação do STF aqui representada pelo acórdão proferido nos autos do Mandado de Segurança impetrado contra ato do Presidente da Comissão Parlamentar Mista de Inquérito do BANESTADO:

COMISSÃO PARLAMENTAR DE INQUÉRITO - PODERES DE INVESTIGAÇÃO (CF, ART. 58, § $3^{\circ}$ ) - LIMITAÇÕES CONSTITUCIONAIS - LEGITIMIDADE DO CONTROLE JURISDICIONAL - POSSIBILIDADE DE A CPI ORDENAR, POR AUTORIDADE PRÓPRIA, A QUEBRA DOS SIGILOS BANCÁRIO, FISCAL E TELEFÔNICO - NECESSIDADE DE FUNDAMENTAÇÃO DO ATO DELIBERATIVO - QUEBRA DE SIGILO ADEQUADAMENTE FUNDAMENTADA - VALIDADE - MANDADO DE SEGURANÇA INDEFERIDO. A QUEBRA DO SIGILO CONSTITUI PODER INERENTE À COMPETÊNCIA INVESTIGATÓRIA DAS COMISSÕES PARLAMENTARES DE INQUÉRITO. - A quebra do sigilo fiscal, bancário e telefônico de qualquer pessoa sujeita a investigação legislativa pode ser legitimamente decretada pela Comissão Parlamentar de Inquérito, desde que esse órgão estatal o faça mediante deliberação adequadamente fundamentada e na qual indique a necessidade objetiva da adoção dessa medida extraordinária. Precedentes. - O sigilo bancário, o sigilo fiscal e o sigilo telefônico (sigilo este que incide sobre os dados/registros telefônicos e que não se identifica com a inviolabilidade das comunicações telefônicas) - ainda que representem projeções específicas do direito à intimidade, fundado no art. $5^{\circ}, \mathrm{X}$, da Carta Política - não se revelam oponíveis, em nosso sistema jurídico, às Comissões Parlamentares de Inquérito, eis que o ato que lhes decreta a quebra traduz natural derivação dos poderes de investigação que foram conferidos, pela própria Constituição da República, aos órgãos de investigação parlamentar. As Comissões Parlamentares de Inquérito, no entanto, para decretar, legitimamente, por autoridade própria, a quebra do sigilo bancário, do sigilo fiscal e/ou do sigilo telefônico, relativamente a pessoas por elas investigadas, devem demonstrar, a partir de meros indícios, a existência concreta de causa provável que legitime a medida excepcional (ruptura da esfera de intimidade de quem se acha sob investigação), justificando a

\footnotetext{
${ }^{12}$ Disponível em:

〈http://www.stf.jus.br/portal/jurisprudencia/listarJurisprudencia.asp?s1=\%28CPI+direito+ao+sil\%EAncio\%29\&base =baseAcordaos\&url=http://tinyurl.com/z5ngw58>. Acesso em: 7 set. 2016.
} 
necessidade de sua efetivação no procedimento de ampla investigação dos fatos determinados que deram causa à instauração do inquérito parlamentar, sem prejuízo de ulterior controle jurisdicional dos atos em referência $\left(\mathrm{CF}\right.$, art. $\left.5^{\circ}, \mathrm{XXXV}\right)$.

(STF - MS 24.817/DF - Relator: Ministro Celso de Mello - DJe de 06/11/200913)

Contudo, as CPIs não podem efetivar buscas e apreensões domiciliares, por serem medidas acobertadas pela cláusula de reserva jurisdicional, conforme ensinamentos de Jessé Cláudio Franco de Alencar:

\footnotetext{
Reafirmamos, portanto, nosso entendimento de que as buscas e apreensões domiciliares fazem parte do monopólio constitucionalmente atribuído aos juízes, a quem as Comissões Parlamentares de Inquérito devem recorrer, fundamentadamente, caso queiram utilizar-se de tal meio de prova. Aliás, os doutrinadores nacionais têm majoritariamente se posicionado de forma semelhante, entre eles Accioli, Sampaio, Pereira, Campos, Ramos e Barroso (ALENCAR, 2005, p. 90).
}

Eventual necessidade de se efetivar medidas sob o manto da cláusula de reserva jurisdicional deverá a CPI requerer ao Judiciário, que detém competência exclusiva para praticálas, tal como disposto no art. 5º, incisos XI e XII, da Constituição da República, que tratam respectivamente da invasão domiciliar e interceptação telefônica.

É assegurada à CPI convocar pessoas para prestarem depoimentos, sob pena de condução coercitiva, já que tal poder está adstrito ao desempenho de suas atribuições investigatórias ${ }^{14}$. Convocação no sentido de obrigatoriedade e não mero convite. Não se constitui em faculdade de atender ou não a convocação realizada pela CPI. Entendemos que a condução coercitiva de testemunha faltosa somente é possível se existir ordem judicial, pois configura ato exclusivo de autoridade judicial (cláusula de reserva jurisdicional).

Não se pode exigir que a pessoa intimada suporte os custos de deslocamento, se o depoimento for marcado fora de seu domicílio, sob pena de ferir o art. 222 do Código de Processo Penal, conforme precedente do STF, que determina que o custo de deslocamento deve ser por conta de quem o convocou ${ }^{15}$.

\footnotetext{
${ }^{13}$ Disponível em:

<http://www.stf.jus.br/portal/jurisprudencia/listarJurisprudencia.asp?s1=\%28CPI+e+quebra+dos+sigilos+\%29\&base =baseAcordaos\&url=http://tinyurl.com/zum3wzg>. Acesso em: 7 set. 2016.

${ }^{14}$ Nesse sentido: TJSP, Pleno, AgRg 48.640-0/3-01, Rel. Des. Dirceu de Mello, data da decisão: 29/04/1998.

${ }^{15} \mathrm{HC}$ 87.2330/MC, Rel. Min. Joaquim Barbosa, DJ 28/11/2005.
} 
Os arts. 411, do Código de Processo Civil e 221, do Código de Processo Penal, elencam as autoridades que gozam da prerrogativa de serem inquiridas em local, dia e hora previamente fixados com a autoridade competente. Tais dispositivos deverão ser observados quando as referidas autoridades forem convocadas para depor perante CPI.

Cumpre registrar que membros dos Tribunais de Contas e do Poder Judiciário poderão ser convocados a prestar depoimentos perante as CPI's, desde que os questionamentos não invadam o mérito dos pareceres ou das decisões proferidas em decorrência do exercício funcional.

Contudo, as referidas autoridades, tais como Ministros do STF, Juízes Federais, Juízes Estaduais e Conselheiros dos Tribunais de Contas não estão obrigadas a comparecer perante CPI's para deporem sobre os atos praticados no exercício de suas funções, ou seja, em decorrência da atividade jurisdicional. Nesse sentido, já decidiu o STF ao conceder a ordem de habeas corpus em favor da Juíza Cláudia Valéria Bastos, convocada para depor perante a CPI do Narcotráfico $^{16}$.

Não se admite a convocação, por CPI criada no nível municipal, de Juízes ou membros de Tribunais de Contas do Estado, vez que "as CPI's municipais não têm competência para investigar atos de autoridades estaduais", respeitando-se a autonomia das unidades federativas (CASTRO, 2003, p. 54-55).

Observe-se que o Presidente e Vice-Presidente da República, Governador e ViceGovernador do Estado, Prefeito e Vice-Prefeito Municipal são autoridades que não poderão ser convocadas pelas CPI's, em obediência ao princípio constitucional da separação e independência dos Poderes, mas tão-somente convidadas, respeitando-se a prerrogativa de função, quando então poderão marcar dia, horário e local para serem ouvidos.

\section{Conclusão}

${ }^{16}$ HC 80089/RJ, Relator Min. Nelson Jobim - Julgamento: 21/06/2000 HC 80089/RJ, Relator Min. Nelson Jobim Julgamento: 21/06/2000, DJ 29/09/2000, p. 71 - RTJ Vol. 00175-01, pp. 00305. 
Os trabalhos desenvolvidos pelas diversas CPI's demonstram o prestígio das funções investigatórias a cargo do Legislativo, homenageando a representatividade popular, preceito fundamental do Estado Democrático de Direito.

A criação da CPI configura instrumento legal e democrático colocado à disposição da minoria das Casas Legislativas nos âmbitos federal, estadual e municipal.

A expressão poderes de investigação próprios das autoridades judiciais, constante do art. 58, § $3^{\circ}$, da Constituição da República de 1988, confere às CPI's poderes que são inerentes à atividade investigativa, tais como, oitiva de testemunhas, requisição de documentos e a quebra dos sigilos bancário, fiscal e telefônico, por serem inerentes ao poder investigatório.

Os referidos atos, para serem praticados pelos membros das CPI's, deverão ser motivados, sob pena de ferir direitos fundamentais e de responder por crime de responsabilidade.

Contudo, determinados atos possuem natureza jurídica de atos exclusivamente jurisdicionais e não poderão ser praticados pelos membros das CPI's, em decorrência do postulado da reserva de jurisdição.

Assim, as CPI's não poderão: decretar a prisão, salvo em flagrante; efetivar busca domiciliar; realizar interceptação telefônica. Tais atos, por previsão expressa da Constituição da República de 1988, somente poderão ser praticados mediante ordem judicial. As CPI's poderão requerer ordem judicial para tais, desde que exista motivação necessária e seja indispensável para sua tarefa investigativa.

Adequada está a delimitação dos poderes conferidos às CPI's, vez que determinados atos são tipicamente e exclusivamente jurisdicionais e jamais poderiam ser praticados pelos parlamentares, membros das referidas comissões, que não estão tecnicamente habilitados a desempenhar, em sua plenitude, poderes de investigação próprios das autoridades judiciais, tal como os magistrados. 


\section{REFERÊNCIAS}

ALENCAR, Jessé Cláudio Franco de. Comissões parlamentares de inquérito no Brasil. Rio de Janeiro: Renovar, 2005.

BARACHO, José Alfredo Oliveira. Teoria geral das comissões parlamentares. 2. ed. Rio de Janeiro: Forense, 2001.

BARROSO, Luís Roberto. Comissões Parlamentares de Inquérito e suas consequências: política, direito e devido processo legal. In: BARROSO, Luís Roberto Temas de Direito Constitucional. Rio de Janeiro: Renovar, 2001.

. Interpretação e aplicação da Constituição. 6. ed. São Paulo: Saraiva, 2004.

BULOS, Uadi Lammêgo. Comissão Parlamentar de Inquérito: técnica e prática. São Paulo: Saraiva, 2001.

CARVALHO, Kátia de. Funcionamento das comissões parlamentares de inquérito na Câmara dos Deputados. Consultoria Legislativa (estudo maio/2004), disponível em:

$<$ http://www2.camara.leg.br/documentos-e-pesquisa/publicacoes/estnottec/areas-daconle/tema6/pdf/2004_4461.pdf >. Acesso 7 set. 2016.

CASTRO, José Nilo de. A CPI municipal. 4. ed. Belo Horizonte: Del Rey, 2003.

FAGUNDES, M. Seabra. $O$ controle dos atos administrativos pelo Poder Judiciário. 6 ed., São Paulo: Saraiva, 1984.

FREITAS, Juarez. A interpretação sistemática do Direito. São Paulo: Malheiros Editores, 1999. . O controle dos atos administrativos e os princípios fundamentais. São Paulo:

Malheiros Editores, 1999.

GONÇALVES, Luiz Carlos dos Santos. Poderes de investigação dascomissões parlamentares de inquérito. São Paulo: Juarez de Oliveira, 2001.

LA COSTITUZIONE ITALIANA. A cura di Renato Fabietti. Edizione integrate commentata. Milano: Mursia, 2000.

LIMA, Eduardo Martins de; DA PIEVE, Flávia Cristina Mendonça Faria. O papel da comissão parlamentar de inquérito do Poder Judiciário na reformulação do exercício da jurisdição. $3^{\circ}$ Encontro Anual da ANPOCS, GT 37 Sociologia e Direito: Explorando as insterseções. 
LIMA, Eduardo Martins de; Da Pieve, Flávia Cristina Mendonça Faria; AGUIAR FILHO, João Costa Aguiar. A comissão parlamentar de inquérito no ordenamento jurídico: origem, histórico, atribuições e limites. Pensar, Fortaleza, v. 16, n. 2, p. 477-508, jul./dez. 2011.

LIMA, Eduardo Martins de; CARDOSO, Lorraine Aparecida de Oliveira. Os poderes instrutórios e de investigação da Comissão Parlamentar de Inquérito. In: Liane Francisca Hüning Birfeld; Laécio Noronha Xavier; Gustavo Ferreira Santos. (Org.). XXIII Congresso Nacional de Pósgraduação e Pesquisa em Direito: Direito e Administração Pública III. 1ed. Santa Catarina: CONPEDI, 2014, p. 448-478.

MARQUES, José Frederico. Elementos de direito processual penal. Campinas: Bokseller, 1997, V. 1.

MEIRELLES, Hely Lopes. Comissões parlamentares de inquérito: estudos e pareceres de Direito Público, RT, 1991, v. 11.

NINA, Carlos Homero Vieira. Comissão parlamentar de inquérito nas constituições brasileiras. Revista de Informação Legislativa. Brasília a. 42 n. 166 abr./jun. 2005.

OLIVEIRA FILHO, João. Comissões parlamentares de inquérito, Revista Forense, vol. 151.

PEIXINHO, Manoel Messias; GUANABARA, Ricardo. Comissões Parlamentares de inquérito: princípios, poderes e limites. Rio de Janeiro: Lumen Juris, 2001.

SALGADO, Plínio. Comissões parlamentares de inquérito: doutrina, jurisprudência e legislação. Belo Horizonte: Del Rey, 2001.

SILVA, Juary C. Ensaio sobre o Poder Judiciário: controle externo, CPI e reforma. Revista Trimestral de Direito Público, São Paulo, n. 28, p. 66-75, 1999.

SILVA, Francisco Rodrigues da. CPIs federais, estaduais e municipais: poderes e limitações. Recife: Ed. do Autor, 2001. 